Research Article

\title{
Preparation of Aluminium-Silver Composite Cutting Tool by Chemical Synthesis
}

\author{
Jayashree Das ${ }^{\dot{A}^{*}}$, Prakash Kumar Sahu ${ }^{\dot{\mathrm{B}}}$, Biswajit Parida ${ }^{\dot{\mathrm{B}}}$, Ashim Guha $^{\dot{\mathrm{C}}}$ and Punya Priya Mishra ${ }^{\dot{\mathrm{A}}}$ \\ ${ }^{\dot{A}}$ Mechanical Engineering Department, Veer Surendra Sai University of Technology, Burla, Orissa, India \\ ${ }^{\dot{B}}$ Mechanical Engineering Department, Indian Institute of Technology, Guwahati, Assam, India \\ ${ }^{\mathrm{C}}$ Mechanical Engineering Department, Bengal Engineering and Science University, Shibpur, West Bengal, India
}

Accepted 10 January 2014, Available online 01 February 2014, Special Issue-2, (February 2014)

\begin{abstract}
The present work is aimed to develop metal toughened aluminium-silver composite which will be used as a cutting tool material. Chemical synthesis using the sol-gel method was carried-out to prepare alumina powder from aluminium nitrate $\mathrm{Al}\left(\mathrm{NO}_{3}\right)_{3}, 9 \mathrm{H}_{2} \mathrm{O}$. Then $\mathrm{AgNO}_{3}$ was well mixed with the prepared $\alpha-\mathrm{Al}_{2} \mathrm{O}_{3}$ powder in aqueous solution followed by evaporation and heating, to get 10 volume percent of $\mathrm{Ag}$ in the $\mathrm{Al}_{2} \mathrm{O}_{3}$-Ag mixture. A conventional powder metallurgical route was followed to prepare $\mathrm{Al}_{2} \mathrm{O}_{3}$-Ag composite pellets. The pellets were first dried at $500^{\circ} \mathrm{C}$ for 2 hours to burn off the PVA, then pre-sintered at $950^{\circ} \mathrm{C}$ for 2 hours and finally sintered at $1600^{\circ} \mathrm{C}$ for 2 hours as soaking time in a furnace. $X R D$ test shows that the phase present in the powder heated at $1600^{\circ} \mathrm{C}$ for 2 hours is $\alpha$-alumina and only silver is present in the developed pellet as a second phase. Bulk density and open porosity of the samples were measured using Archimedes principle and employing boiling water method. Bulk densities of some of the composite pellets were found nearly $3 \mathrm{~g} / \mathrm{cc}$. Attempt should be made to improve the density in order to use the developed powder as cutting tool material. Ceramic cutting tools can be used in metal cutting, and can keep their hardness, strength, abrasion resistance and long performance life under high cutting speed. With these special mechanical properties, ceramic cutting tools will certainly substitute high speed steel cutting tools in many fields.
\end{abstract}

Keywords: Aluminium-silver composite, Sol-gel method, Bulk-density, Open porosity, Hardness

\section{Introduction}

\subsection{Cutting Tool}

The demand of the manufacturing industries in the latter half of nineteenth century has led to the development of improved machine tools, cutting tools and production processes. The cutting tool is one of the important elements in realizing the full potential out of any metal cutting operation. Tool material have improved rapidly during the last few decades, and in many instances the development of new tool material has necessitated change in the design trend of machining tool to make full use of the potentialities of tool materials for higher productivities. Progress from carbon tool steel, HSS and cast alloys to carbide and ceramics has facilitated the application of higher speed at each stage of development, because improvements achieved in properties of tool materials. Among the available tool materials we have chosen ceramic for further development of cutting tool.

\subsection{Ceramic Cutting Tool}

Ceramics are nonmetallic materials. This puts them in an entirely different category than HSS and carbide tool

*Corresponding author: Jayashree Das

DOI: http://dx.doi.org/10.14741/ijcet/spl.2.2014.17 materials. The use of ceramics as cutting tool material has distinct advantages and disadvantages. The application of ceramic cutting tools is limited because of their extreme brittleness. The transverse rupture strength (TRS) is very low. This means that they will fracture more easily when making heavy or interrupted cuts. However, the strength of ceramics under compression is much higher than HSS and carbide tools. There are two basic types of ceramic material: hot-pressed and cold-pressed. In hot-pressed ceramics, usually black or gray in color, the aluminum oxide grains are pressed together under extremely high pressure and at a very high temperature to form a billet. The billet is then cut to insert size. With cold-pressed ceramics, usually white in color, the aluminum oxide grains are pressed together, again under extremely high pressure but at a lower temperature.

Ceramics may not be the all-around tool for the average shape they can be useful in certain applications. Ceramic tools have been alloyed with zirconium (about $15 \%$ ) to increase their strength. Many ceramic tool manufacturers are recommending the use of ceramic tools for both rough cutting and finishing operations. Practical shop experience indicates that these recommendations are somewhat optimistic. To use ceramic tools successfully, insert shape, work material condition, machine tool capability, set-up, and general machining conditions must all be correct. High rigidity of machine tool and set-up is 
Dearnley et al. (1982) studied the stringent and complex demands put upon tool materials, it is often said that the ideal material should therefore have the hardness of diamond, the toughness of high-speed steel and the chemical inertness of alumina. A. Senthil Kumar et al. (2007) developed, yttria and ceria toughened alumina (YCTA) ternary ceramic composite for cutting tool application. Ersan Aslan et al. (2007) present the paper outlines an experimental study to achieve this by employing Taguchi techniques. Combined effects of three cutting parameters, namely cutting speed, feed rate and depth of cut on two performance measures, flank wear and surface roughness $\left(R_{\mathrm{a}}\right)$, were investigated employing an orthogonal array and the analysis of variance (ANOVA). Shi-Xue Song et al. (2003) was fabricated $\mathrm{Al}_{2} \mathrm{O}_{3} / \mathrm{Ti}$ $\left(\mathrm{C}_{0.3} \mathrm{~N}_{0.7}\right)$ cutting tool material successfully using a new kind of sintering technique, i.e. repetitious-hot-pressing technique. Yang et al. (1969) investigated the strengthening and toughening mechanisms of hot-pressed Ce-TZP/Al ${ }_{2} \mathrm{O}_{3}$ ceramics. B. Smuk et al. (2003) presented a series of ceramic tool materials based on $\mathrm{Al}_{2} \mathrm{O}_{3}$ with $\mathrm{ZrO}_{2}$. Experiments on ceramic materials with different contents of $\mathrm{ZrO}_{2}$ addition and different phase compositions in the delivered state were carried out. Huang et al. (2002) fabricated $\mathrm{Al}_{2} \mathrm{O}_{3} /(\mathrm{W}, \mathrm{Ti}) \mathrm{C}$ composite ceramic materials reinforced by rare earth additives by the hot pressing technique. Microstructure, flexural strength, toughening and strengthening mechanisms are analyzed. The maximum flexural strength and fracture toughness of the yttrium reinforced $\mathrm{Al}_{2} \mathrm{O}_{3} /(\mathrm{W}, \mathrm{Ti}) \mathrm{C}$ ceramic are $853 \mathrm{MPa}$ and $6.1 \mathrm{MPa}$, respectively, which are approximately $20 \%$ and $16 \%$ higher than for the corresponding material without yttrium. Chonghai Xu et al. (2006) studied that the addition of rare earth additives such as yttrium of a suitable amount in a proper way can notably improve the flexural strength and fracture toughness and fracture resistance of $\mathrm{Al}_{2} \mathrm{O}_{3} /(\mathrm{W}, \mathrm{Ti}) \mathrm{C}$ ceramic material. L.A. Dobrza nski et al. (2005) presented investigation results of structure and properties of the coatings deposited with the PVD and CVD techniques on cutting inserts made from the $\mathrm{Al}_{2} \mathrm{O}_{3}+\mathrm{ZrO}_{2}$ oxide tool ceramics.

\section{Experimental Work}

\subsection{Chemical Synthesis}

In a typical experiment, boehmite solution was prepared by hydrolyzing aluminium nitrate, $\mathrm{Al}\left(\mathrm{NO}_{3}\right)_{3}, 9 \mathrm{H}_{2} \mathrm{O}$ dissolved in distilled water followed by peptization using nitric acid. The obtained boehmite was first heated in a sand bath heater, and then heating was done in a medium temperature furnace and then high temperature furnace in subsequent temperatures to get $\alpha$-alumina. Some amount of prepared powder $(\sim 2 \mathrm{~g})$ was separated for X-ray diffraction.

\subsection{Preparation of Alumina Powder by Chemical Synthesis}

i. $56.752 \mathrm{gm}$ aluminium nitrate $\left(\mathrm{Al}\left(\mathrm{NO}_{3}\right)_{3}, 9 \mathrm{H}_{2} \mathrm{O}, \mathrm{AR}\right.$ Grade MERCK Ltd., India) was taken in a large beaker (2000ml) and dissolved in $400 \mathrm{ml}$ distilled water (Figure$2.1[\mathrm{a}])$.

ii. Then the beaker was placed on a magnetic stirrer- cum heater and kept under stirring. The temperature was maintained at $\sim 363 \mathrm{~K}$, (Figure- $2.1[\mathrm{~b}]$ ).

iii. Ammonium hydroxide $\left(\mathrm{NH}_{4} \mathrm{OH}\right.$, i.e. $25 \% \mathrm{NH}_{3}$ in water) was slowly added to the solution with the help of a glass dropper, (Figure- 2.1[c]).

iv. Gel formation was observed. Controlled addition of $\mathrm{NH}_{4} \mathrm{OH}$ was carried out till gel formation continued.

v. The gel was then filtered ( 41 hours), (Figure- 2.2[d, e]).

vi. The filtered gel (boehmite, $\mathrm{AlOOH}$ ) was taken out and kept in a separate beaker. Some amount of distilled water ( $400 \mathrm{ml})$ was added, (Figure- 2.3[f]).

vii. It was very slowly (drop by drop) peptized by $1: 1$ solution by distilled water $(20 \mathrm{ml})$ and $\mathrm{HNO}_{3}(20 \mathrm{ml})$, (GR $70 \%$ MERCK Ltd., India) keeping the temperature $\sim 333 \mathrm{~K}$. The peptization process was continued till $\mathrm{pH} 3.5$ of the solution was achieved, Figure- $2.3[\mathrm{~g}]$ ).

viii. The mixture was kept under magnetic stirring for a period of 4 hours, (Figure- 2.3[h]).

ix. The solution was heated at $\sim 493 \mathrm{~K}$ for nearly 13 hours in a sand-bath heater,(Figure-2.4[i, j, k]).

$\mathrm{x}$. The obtained powder was ground in an Agate pestle and mortar and weight was taken, (Figure- $2.5[1, \mathrm{~m}]$ ).

xi. The ground powder was first heated at $500^{\circ} \mathrm{C}$ for 2 hours in a furnace, furnace cooled and powder weight was taken after cooling $6.082 \mathrm{gm}$ then obtained powder was ground in an Agate pestle and mortar, weight was taken $6.066 \mathrm{gm}$. Then heated at $1200^{\circ} \mathrm{C}$ for 2 hours (Figure$2.6[\mathrm{n}, \mathrm{o}]$ ), furnace cooled, powder Weight was taken after cooling $5.584 \mathrm{gm}$ and again the obtained powder was ground in a Agate pestle and mortar, finally powder weight was taken 5.562gm, (Figure-2.7).

\subsection{Flow Chart for Preparation of $\alpha$-Alumina Powder}

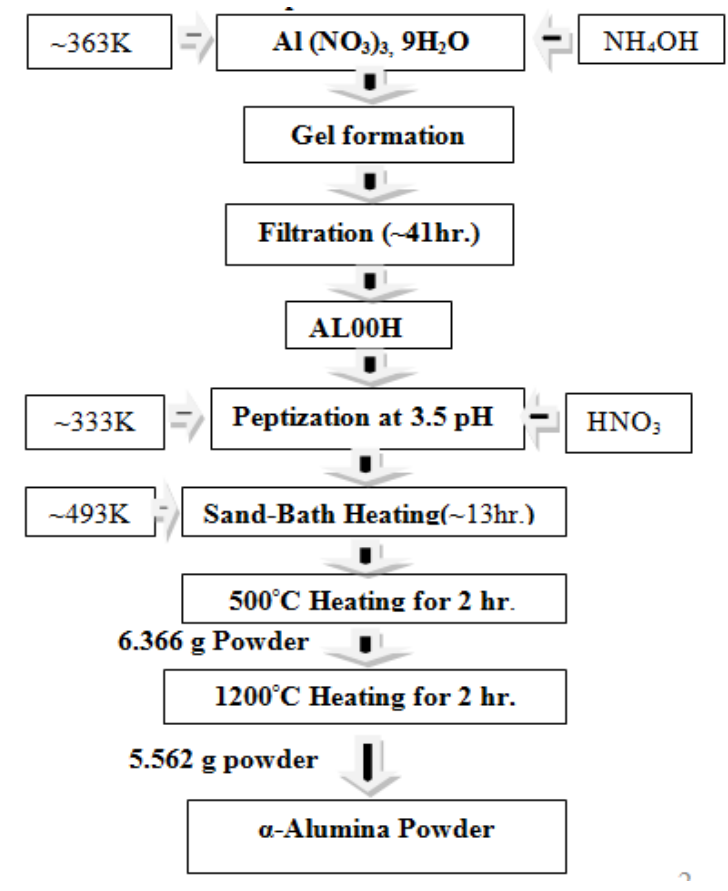

94 | International Conference on Advances in Mechanical Sciences 2014 


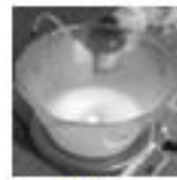

(a)

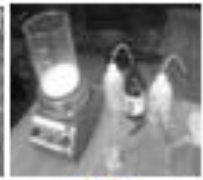

(b)
Figure 2.1 -Gel preparation

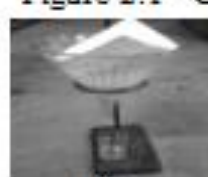

(d)

Figure 2.2 - Filtration

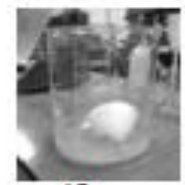

(f)

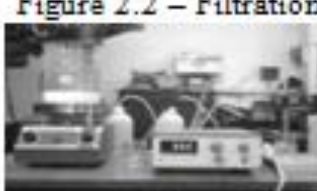

(g)

Figure 2.3 - Peptization (c)

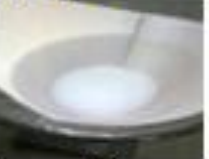

(e)

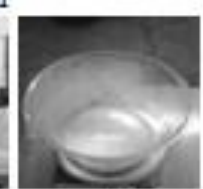

(h)

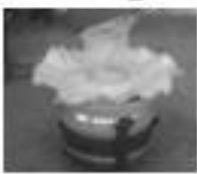

(i)

(j)

(k)

Figure 2.4 - Sand bath heating

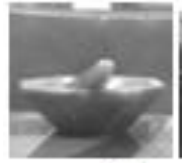

(1)

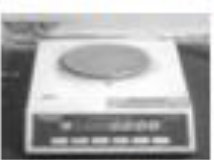

(m)

Figure 2.5 - Measurement

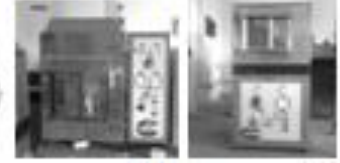

(n) (o)
Figure 2.6-Furnace
Figure 2.7-Alpha Alumina Powder

2.5 Flow Chart to Prepare Alumina-Silver Composite Pellet

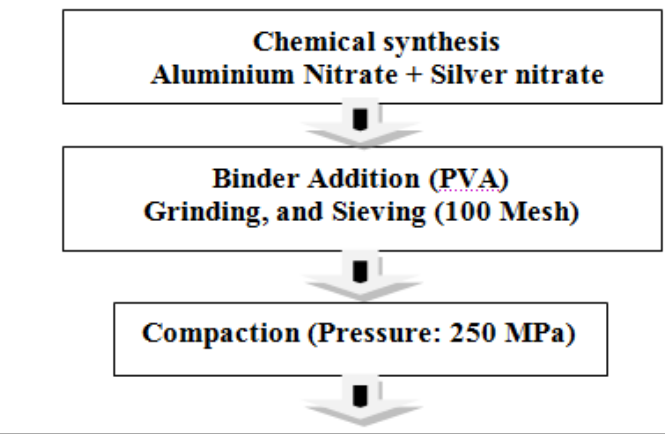

Heating \& presintering

(First at $500^{\circ} \mathrm{C}$, then at $950^{\circ} \mathrm{C}$ for $2 \mathrm{hr}, @ 4^{\circ} \mathrm{C} / \mathrm{min}$ )

Sintering

(At $1600^{\circ} \mathrm{C}$ for $2 \mathrm{hr}, @ 3^{\circ} \mathrm{C} / \mathrm{min}$ )

\subsection{Prepared Alumina-Silver Composite Pellet}

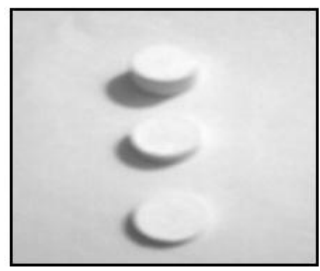

$\mathrm{Al}_{2} \mathrm{O}_{3}$ Pellets, Sample-1, $2 \& 3$ Sample-4 \& 5

\section{Result and Discussion}

Alumina-silver composite has been successfully developed by solution sol-gel route and conventional powder metallurgical process. Test of the nature of the composites and characterization of their properties are necessary supplements. These aspects are presented in the different subsections.

\subsection{Phase Identification}

Phase identification of the developed powder heated at $500^{\circ} \mathrm{C}, 950{ }^{\circ} \mathrm{C}$ and $1600{ }^{\circ} \mathrm{C}$ respectively for 2 hours was made by $\mathrm{X}$-ray diffraction analysis using an X-ray diffract meter.

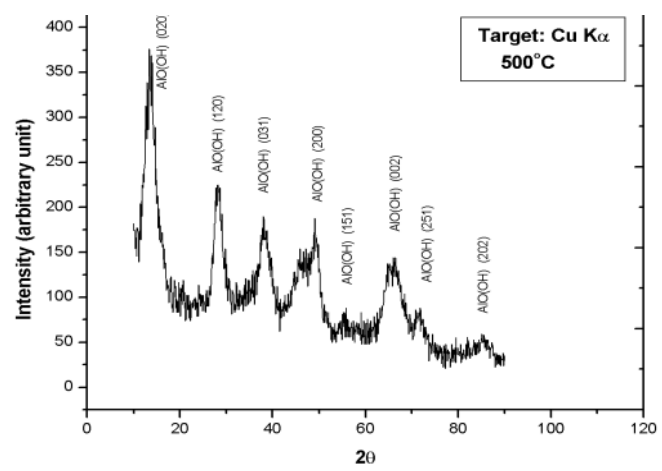

Fig. 3.1 XRD scan for the developed powder heated at $50{ }^{\circ} \mathrm{C}$ for 2 hours. Phase: boehmite $-\mathrm{AlO}(\mathrm{OH})$

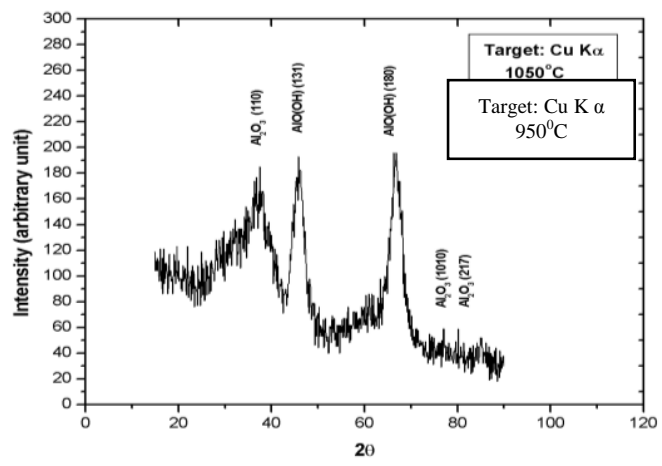

Fig. 3.2 XRD scan for the developed powder heated at $950{ }^{\circ} \mathrm{C}$ for 2 hours. Phases: boehmite- $\mathrm{AlO}(\mathrm{OH}), \quad \alpha-$ alumina $-\mathrm{Al}_{2} \mathrm{O}_{3}$ 


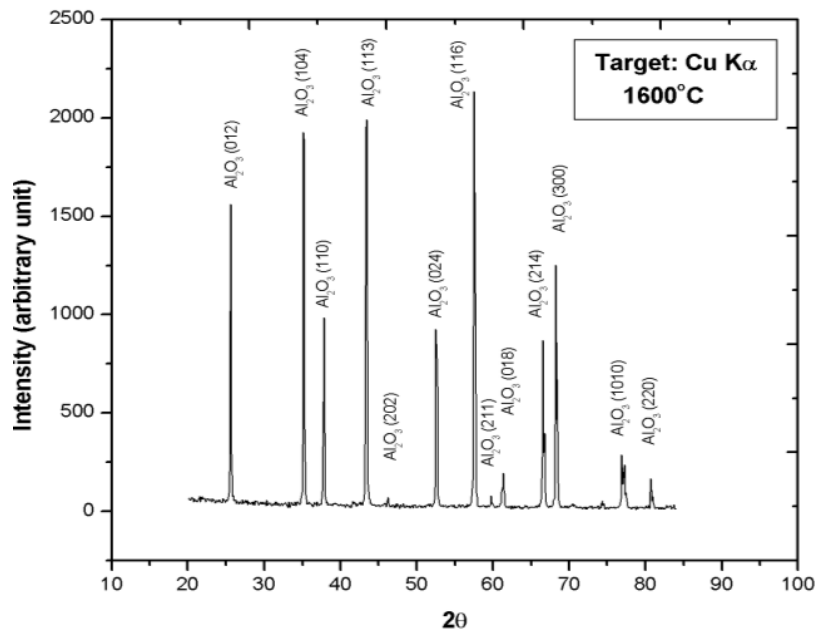

Fig. 3.3 XRD scan for the developed powder heated at $1600^{\circ} \mathrm{C}$ for 2 hours. Phase $\alpha$-alumina $-\mathrm{Al}_{2} \mathrm{O}_{3}$

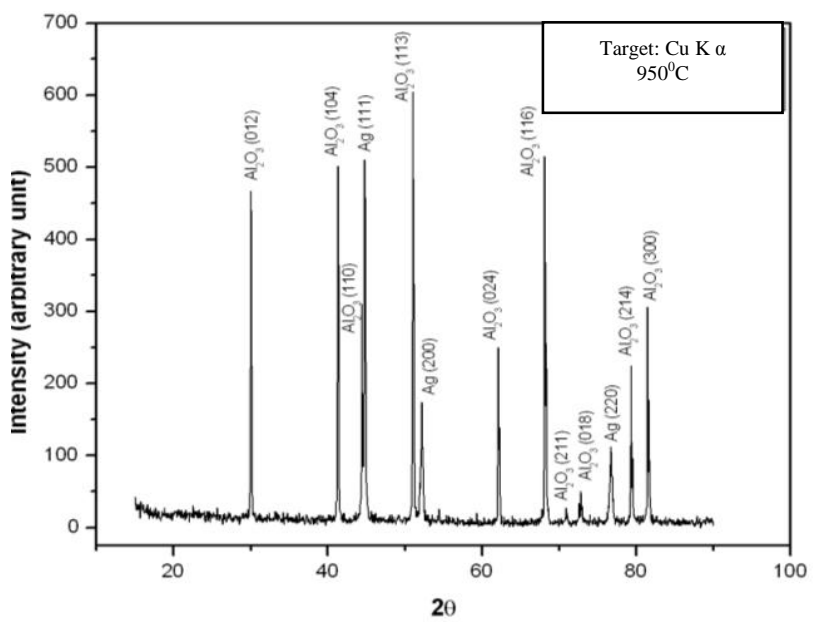

Fig. 3.4 XRD scan for the developed pellet sintered at $950^{\circ} \mathrm{C}$ for 2 hours. Phases: $\alpha$-alumina $-\mathrm{Al}_{2} \mathrm{O}_{3}$, Silver $-\mathrm{Ag}$

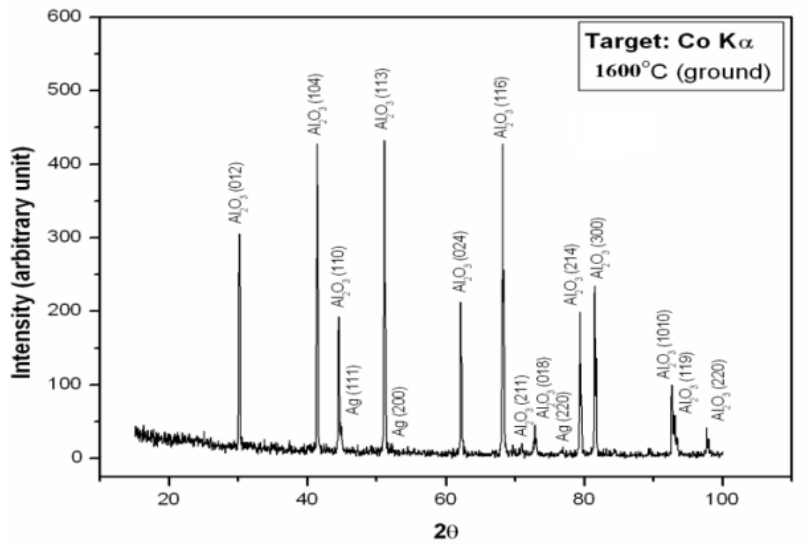

Fig.3.5 XRD scan for the developed pellet sintered at $1600^{\circ} \mathrm{C}$ for 2 hours. Phases: $\alpha$-alumina $-\mathrm{Al}_{2} \mathrm{O}_{3}$, Silver- $\mathrm{Ag}$

From the XRD analysis, fig 3.1 shows that the phase present in the powder heated at $500^{\circ} \mathrm{C}$ for 2 hours is boehmite $\mathrm{AlO}(\mathrm{OH})$ (Ref. 083-2384 JCPDS). Fig 3.2 shows for the powder heated at $950{ }^{\circ} \mathrm{C}$ for 2 hours, phases present are boehmite $\mathrm{AlO}(\mathrm{OH}), \alpha$-alumina - $\mathrm{Al}_{2} \mathrm{O}_{3}(821$ 468 JCPDS). Fig 3.3 shows for the powder heated at $1600^{\circ} \mathrm{C}$ for 2 hours, phase present is $\alpha$-alumina $-\mathrm{Al}_{2} \mathrm{O}_{3}$. Fig 3.4 shows that phases present in the pre-sintered pellet at $950^{\circ} \mathrm{C}$ for 2 hours are $\alpha$-alumina $-\mathrm{Al}_{2} \mathrm{O}_{3}$, Silver $-\mathrm{Ag}$ (Ref.04-0783 JCPDS). Fig 3.5 also shows that phases present in the sintered pellet at $1600^{\circ} \mathrm{C}$ for 2 hours are $\alpha$ alumina $-\mathrm{Al}_{2} \mathrm{O}_{3}$, Silver $-\mathrm{Ag}$.

\subsection{Measurement of Sintered Density}

Table3.1 Green densities of pellet

\begin{tabular}{llllcc}
\hline Material & $\begin{array}{l}\text { Diameter } \\
\text { of pellet } \\
(\phi) \mathrm{mm}\end{array}$ & $\begin{array}{l}\text { Thickness } \\
\text { of pellet } \\
(\mathrm{L}) \mathrm{mm}\end{array}$ & $\begin{array}{l}\text { Volume } \\
(\mathrm{V}) \mathrm{cc}\end{array}$ & $\begin{array}{l}\text { Weight } \\
(\mathrm{W}) \mathrm{g}\end{array}$ & $\begin{array}{l}\text { Green } \\
\text { density } \\
\mathrm{g} / \mathrm{cc}\end{array}$ \\
\hline $\mathrm{Al}_{2} \mathrm{O}_{3}$ & 10.34 & 7.62 & 0.637 & 1.258 & 1.9748 \\
& 10.34 & 4.42 & 0.371 & 0.7494 & 2.0199 \\
& 10.34 & 2.50 & 0.210 & 0.4245 & 2.0223 \\
\hline $\mathrm{Al}_{2} \mathrm{O}_{3}$ & 10.34 & 4.82 & 0.404 & 0.8315 & 2.0546 \\
$+\mathrm{Ag}$ & 10.34 & 2.56 & 0.215 & 0.4909 & 2.2843 \\
& & & & &
\end{tabular}

Table3.2 Densities of pellets heated after $500^{\circ} \mathrm{C}$

\begin{tabular}{llllll}
\hline Material & $\begin{array}{l}\text { Diameter } \\
\text { of pellet } \\
(\phi) \mathrm{mm}\end{array}$ & $\begin{array}{l}\text { Thickness } \\
\text { of pellet } \\
(\mathrm{L}) \mathrm{mm}\end{array}$ & $\begin{array}{l}\text { Volume } \\
(\mathrm{V}) \mathrm{cc}\end{array}$ & $\begin{array}{l}\text { Weight } \\
(\mathrm{W}) \mathrm{g}\end{array}$ & $\begin{array}{l}\text { Density } \\
\mathrm{g} / \mathrm{cc}\end{array}$ \\
\hline & 10.34 & 7.62 & 0.63818 & 1.2287 & 1.9253 \\
$\mathrm{Al}_{2} \mathrm{O}_{3}$ & 10.34 & 4.56 & 0.38290 & 0.7288 & 1.9033 \\
& 10.34 & 2.62 & 0.22004 & 0.4112 & 1.8690 \\
\hline $\mathrm{Al}_{2} \mathrm{O}_{3}$ & 10.34 & 4.82 & 0.39485 & 0.7796 & 1.9739 \\
$+\mathrm{Ag}$ & 10.34 & 2.56 & 0.21830 & 0.4621 & 2.1167
\end{tabular}

Table3.3 Pre-sintered densities of pellets heated at $950^{\circ} \mathrm{C}$

\begin{tabular}{llllll}
\hline Material & $\begin{array}{l}\text { Diameter } \\
\text { of pellet } \\
(\phi) \mathrm{mm}\end{array}$ & $\begin{array}{l}\text { Thickness } \\
\text { of pellet } \\
(\mathrm{L}) \mathrm{mm}\end{array}$ & $\begin{array}{l}\text { Volume } \\
(\mathrm{V}) \mathrm{cc}\end{array}$ & $\begin{array}{l}\text { Weight } \\
(\mathrm{W}) \mathrm{g}\end{array}$ & $\begin{array}{l}\text { Density } \\
\mathrm{g} / \mathrm{cc}\end{array}$ \\
\hline $\mathrm{Al}_{2} \mathrm{O}_{3}$ & 10.32 & 7.62 & 0.6373 & 1.2271 & 1.9252 \\
& 10.32 & 4.52 & 0.3780 & 0.7269 & 1.9226 \\
& 10.32 & 2.68 & 0.2241 & 0.4097 & 1.8276 \\
\hline $\mathrm{Al}_{2} \mathrm{O}_{3}$ & 10.36 & 4.74 & 0.3995 & 0.7787 & 1.9488 \\
$+\mathrm{Ag}$ & 10.32 & 2.72 & 0.2275 & 0.4610 & 2.0260 \\
\hline
\end{tabular}

Table3.4 Sintered densities of pellets heated at $1600^{\circ} \mathrm{C}$

\begin{tabular}{lllllll}
\hline Material & $\begin{array}{l}\text { Diameter } \\
\text { pellet } \\
\mathrm{mm}\end{array}$ & $\begin{array}{l}\text { of } \\
(\phi)\end{array}$ & $\begin{array}{l}\text { Thickness } \\
\text { of pellet }(\mathrm{L}) \\
\mathrm{mm}\end{array}$ & $\begin{array}{l}\text { Volume } \\
(\mathrm{V}) \mathrm{cc}\end{array}$ & $\begin{array}{l}\text { Weight } \\
(\mathrm{W}) \mathrm{g}\end{array}$ & $\begin{array}{l}\text { density } \\
\mathrm{g} / \mathrm{cc}\end{array}$ \\
\hline $\mathrm{Al}_{2} \mathrm{O}_{3}$ & 9.16 & 6.72 & 0.44284 & 1.2219 & 2.7590 \\
& 9.22 & 4.05 & 0.26706 & 0.7223 & 2.7048 \\
& 9.22 & 2.36 & 0.15688 & 0.4080 & 2.6006 \\
\hline $\mathrm{Al}_{2} \mathrm{O}_{3}$ & 9.00 & 4.02 & 0.25574 & 0.7215 & 2.8212 \\
$+\mathrm{Ag}$ & 9.02 & 2.12 & 0.13546 & 0.4065 & 3.0009 \\
& & & & & & \\
\hline
\end{tabular}

Table 3.1 shows the green densities of the pellets compacted at $250 \mathrm{MPa}$ pressure. Densities of the pellets heated at $500^{\circ} \mathrm{C}$, pre-sintered densities at $950^{\circ} \mathrm{C}$ and sintered densities at $1600^{\circ} \mathrm{C}$ are shown in table $3.2,3.3$ and 3.4 respectively. The sample pellets are first heated at $500^{\circ} \mathrm{C}$ to burn off the polyvinyl alcohol (PVA) binder. Due to the above mentioned weight loss; densities of the pellets have decreased a little. The pellets were then presintered at $950^{\circ} \mathrm{C}$ for 2 hours. At this stage the weight loss

96 | International Conference on Advances in Mechanical Sciences 2014 
is mainly due to evaporation of silver from the outer surface of the pellets. The pellets were finally sintered at $1600^{\circ} \mathrm{C}$ for 2 hours. Sintered densities of the developed alumina-silver composite pellets ware found higher than that of pure alumina pellet.

\subsection{Bulk density and open porosity of the samples}

Table3.5 Bulk density and open porosity of the samples

\begin{tabular}{llllll}
\hline Material & $\begin{array}{l}\text { Dry } \\
\text { weight } \\
\left(\mathrm{W}_{\mathrm{d}}\right) \mathrm{g}\end{array}$ & $\begin{array}{c}\text { Suspende } \\
\mathrm{d} \text { weight } \\
\left(\mathrm{W}_{\text {sus }}\right) \mathrm{g}\end{array}$ & $\begin{array}{l}\text { Saturated } \\
\text { weight } \\
\left(\mathrm{W}_{\text {sat }}\right) \mathrm{g}\end{array}$ & $\begin{array}{l}\text { Bulk } \\
\text { density } \\
(\rho) \mathrm{g} / \mathrm{cc}\end{array}$ & $\begin{array}{l}\text { Open } \\
\text { porosit } \\
\left(\mathrm{p}_{\mathrm{o}}\right)\end{array}$ \\
\hline & 1.240 & 0.350 & 1.281 & 3.54 & 11.70 \\
$\mathrm{Al}_{2} \mathrm{O}_{3}$ & 0.732 & 0.230 & 0.761 & 3.18 & 12.60 \\
& 0.413 & 0.111 & 0.425 & 3.72 & 10.80 \\
\hline $\mathrm{Al}_{2} \mathrm{O}_{3}$ & 0.730 & 0.213 & 0.753 & 3.42 & 10.79 \\
$+\mathrm{Ag}$ & 0.430 & 0.112 & 0.442 & 3.84 & 10.71 \\
\hline
\end{tabular}

Bulk density and open porosity of the sintered pellets were obtained using Archimedes principle and employing boiling water method. The skins of the sintered pellets were lightly abraded to clear-off the unwanted loose particles pairs to density measurements. Bulk density and open porosity of the samples were measured using Archimedes principle and employing boiling water method. Bulk densities of some of the composite pellets were found nearly $3 \mathrm{~g} / \mathrm{cc}$. Attempt should be made to improve the density in order to use the developed powder as cutting tool material.

\subsection{Hardness of the developed pellets}

Table 3.6 Hardness of the developed pellets

\begin{tabular}{lcclll}
\hline Material & $\begin{array}{l}\text { Load } \\
(\mathrm{gf})\end{array}$ & $\begin{array}{l}\text { Time } \\
(\mathrm{sec})\end{array}$ & $(\mathrm{d} 1) \mu \mathrm{m}$ & $\begin{array}{l}(\mathrm{d} 2) \\
\mu \mathrm{m}\end{array}$ & $\begin{array}{l}\text { Hardness } \\
(\mathrm{HV})\end{array}$ \\
\hline & 200 & 15 & 19.5 & 19.5 & 975 \\
$\mathrm{Al}_{2} \mathrm{O}_{3}$ & 200 & 15 & 19 & 19 & 1027 \\
& 200 & 15 & 19 & 19.5 & 1001 \\
\hline $\mathrm{Al}_{2} \mathrm{O}_{3}+$ & 200 & 15 & 20 & 19.5 & 955 \\
$\mathrm{Ag}$ & 200 & 15 & 19.5 & 20 & 950 \\
\hline
\end{tabular}

One of the most useful properties of tools is hardness. The hardness of a material is usually defined as the resistance to permanent deformations like abrasion wear, indentation, scratching, grooving etc. The hardness of a material is a direct result of interatomic forces acting on the surface, which again depends upon the strength of chemical bonding, crystal structure and the plastic deformation. The hardness of the present ceramic pellets has been measured in a Vickers Hardness tester. Ceramic cutting tools can be used in metal cutting, and can keep their hardness, strength, abrasion resistance and long performance life under high cutting speed. With these special mechanical properties, ceramic cutting tools will certainly substitute high speed steel cutting tools in many fields.

\subsection{Indented micrograph of developed pellets}

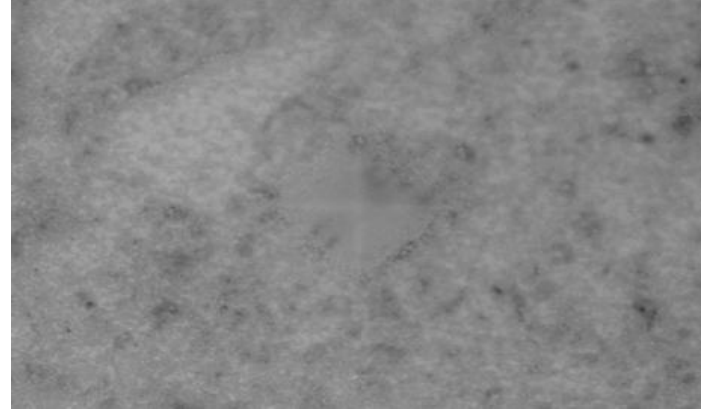

Fig 3.6 Indented with 200gf load of Sample 3

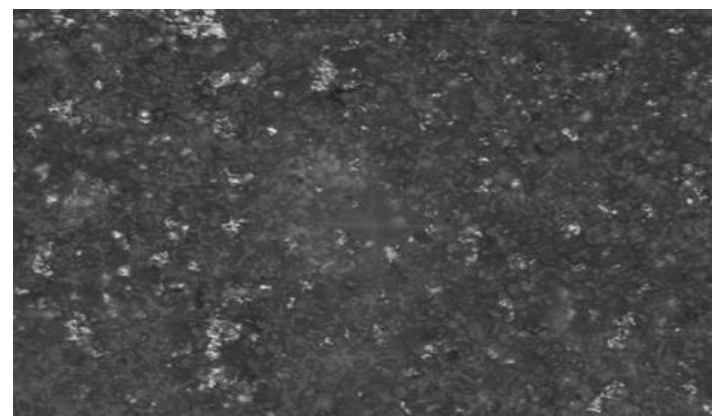

Fig 3.7 Indented with 200gf load of Sample 4

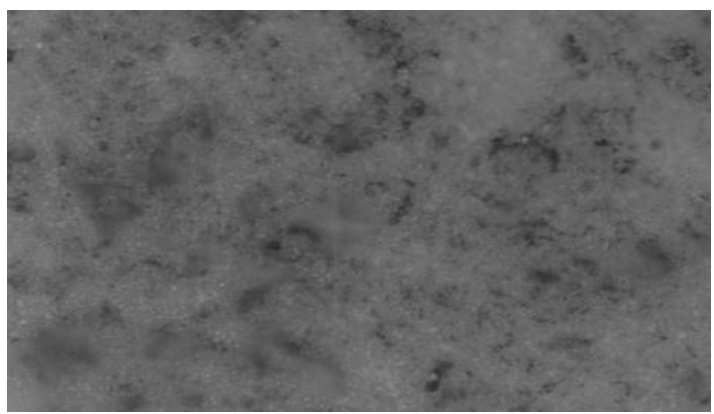

Fig 3.8 Indented with 200gf load of Sample 5

Figure 3.6, 3.7, 3.8 are the sample indented micrograph of the samle-3, 4, 5 respectively for the measurement of the hardness. The maximum hardness was $1027 \mathrm{HV}$.

\section{Conclusions}

- Initial powder of $\alpha$-alumina and silver nitrate can easily be obtained through chemical synthesis

- Alumina-silver composite can be obtained from the initial powder of $\alpha$-alumina and silver nitrate from conventional sintering root.

- X-ray diffraction analysis indicates presence of only $\alpha$-alumina and silver in the composite

- Obtained density of alumina-silver composite pellet is quite well

- Varying the process parameter of compaction and sintering, higher density of the composite is expected to be achieved which will result in silver toughened alumina composite that in turn will lead to development of advanced ceramic cutting tool material. 


\section{References}

P.A. Dearnley and E.M Trent, (1982), Wear mechanisms of coated carbide tools, Metals Technology, vol. 9, 60-75

A.K. Dutta, PhD Thesis, IIT, Kharagpur (1999).

A. Senthil Kumar (2007), Development of yttria and ceria toughened alumina composite for Cutting tool application, International Journal of Refractory Metals and Hard Materials, Vol 25, pp 214-219.

S H. Avner ( 1974) Introduction to physical metallurgy. 2nd Ed. New York. McGraw-Hill.

E. Aslan, N. Camuscu and B. Birgoren (2007), Design Optimization of cutting Parameters when turning hardened AISI 4140 steel (63 HRC) with Al2O3 + TiCN Mixed ceramic tool, Materials and Design, Vol. 28, pp 1618-1622.

S. Song, X. Ai, J. Zhao and C. Huang (2003), $\mathrm{Al}_{2} \mathrm{O}_{3} / \mathrm{Ti} / \mathrm{Ti}$ (C0.3N0.7) cutting tool material, Materials Science and Engineering, vol. 356, pp43-47.
Y. Li, J. Chu, Wang, G. Chao, Min, S. Lin, Chen, T. Cai, Yashima and Masatomo (2006), Investigation on strengthening and toughening mechanisms of Ce-TZP/Al2O3 nanocomposites, Metallurgical and Materials Transactions, vol. 37, pp. 1969-1975.

B. Smuk, M. Szutkowska, and J.Walter (2003), Alumina ceramics with partially Stabilized Zirconia for cutting tools, Journal of Materials Processing Technology, vol-133, pp 195198.

Z. Huang, L. Zhang, L. He, H.L. Liu, J. Sung, and B. Fung, X. Ai (2002), A Study on The Development of Composite ceramic tool material $\mathrm{ZrO} 2(\mathrm{~W}, \mathrm{Ti}) \mathrm{C}$ and its cutting Performance, Material processing technology, vol-129, pp.349-353

C. Xu, C. Huang and X. Ai (2006), Toughening and strengthening of advanced ceramics with rare earth additives, Ceramics International, vol 32, pp 423-429.

L.A. Dobrzanski, J. Mikula (2005), The structure and. functional properties of PVD and CVD Coated $\mathrm{Al} 2 \mathrm{O} 3+\mathrm{ZrO} 2$ oxide tool ceramics, Material Processing Technology, vol. 167, pp. $438-$ 446. 